\title{
Prediction of Students' Ability to Difficulty Level of Problem Based on Linear Method
}

\author{
Prediksi Kemampuan Siswa terhadap Tingkat Kesulitan Soal Berbasis \\ Metode Linear
}

\author{
Hervit Ananta Vidada ${ }^{1)}$, Eko M. Yuniarno ${ }^{2)}$, Supeno Mardi S.N. ${ }^{3)}$, Umi Laili Yuhana ${ }^{4)}$ \\ ${ }^{1,2,3)}$ Department of Electrical Engineering, Institut Teknologi Sepuluh Nopember Surabaya, Indonesia \\ ${ }^{4)}$ Department of Informatics, Institut Teknologi Sepuluh Nopember, Surabaya, Indonesia \\ ${ }^{1)}$ hervit.17071@mhs.its.ac.id \\ 2) ekomulyanto@ee.its.ac.id \\ 3) mardi@ee.its.ac.id \\ 4)yuhana@if.its.ac.id
}

\begin{abstract}
Knowing the ability of students is something that is important to arrange questions correctly, those are questions with the appropriate level of difficulty. However, in general the questions are arranged assuming the students 'abilities are the same, so the results obtained do not adequately reflect the students' actual abilities. This study focuses on the prediction of the ability of 6th grade students in mathematics. Data obtained from 400 exam questions with 8 materials worked on by 23 students. Student ability categories are grouped into 3, namely high ability, medium ability, and low ability. Difficulty problems are grouped into difficult questions, medium questions, and easy questions based on the assessment of 5 different classes. Our research uses the linear regression method and successfully shows that there is a close relationship between students' abilities and the level of difficulty of the questions. The level of difficulty of the questions contributed $63 \%$ to the ability of students. Standard error 0.04905 means that the regression model is the right model in determining students' abilities.
\end{abstract}

Keywords: Regression linear; Student ability; Prediction.

\begin{abstract}
Abstrak-, Mengetahui kemampuan siswa merupakan sesuatu yang penting untuk menyusun soal ujian dengan tepat, yaitu soal dengan tingkat kesulitan yang sesuai. Namun pada umumnya soal ujian disusun dengan asumsi kemampuan siswa adalah sama, maka hasil yang didapatkan kurang menggambarkan kemampuan siswa sebenarnya. Penelitian ini fokus pada prediksi kemampuan siswa kelas 6 mata pelajaran matematika. Data didapatkan dari 400 soal ujian dengan 8 materi yang dikerjakan oleh 23 siswa. Kategori kemampuan siswa dikelompokkan menjadi 3 yaitu kemampuan tinggi, kemampuan sedang, dan kemampuan rendah. Kesulitan soal dikelompokkan dalam soal sulit, soal sedang, dan soal mudah berdasarkan penilaian dari 5 guru kelas yang berbeda. Penelitian kami menggunakan metode regresi linear dan berhasil menunjukkan bahwa ada hubungan yang erat antara kemampuan siswa dengan tingkat kesulitan soal. Tingkat kesulitan soal memberikan kontribusi sebesar 63\% terhadap kemampuan siswa. Standar error 0,04905 artinya model regresi merupakan model yang tepat dalam menentukan kemampuan siswa
\end{abstract}

Kata Kunci: Regresi linear; Kemampuan siswa; Prediksi. 


\section{PENDAHULUAN}

Prediksi adalah suatu proses memperkirakan secara sistematis tentang sesuatu yang mungkin terjadi di masa depan berdasarkan informasi masa lalu dan sekarang yang dimiliki. Prediksi tidak harus memberikan jawaban secara pasti tentang kejadian yang akan terjadi, melainkan berusaha untuk mencari jawaban sedekat mungkin kejadian yang akan terjadi (Herdianto, 2013:8). Memprediksi kemampuan siswa dalam sebuah Lembaga Pendidikan adalah penting, karena hasil prediksi dapat digunakan sebagai pertimbangan dalam pemberian materi pelajaran, penyusunan soal, dan memetakan kemampuan siswa[1].

Matematika merupakan pelajaran wajib di pendidikan dasar dengan beberapa materi didalamnya. Tetapi banyak siswa sekolah dasar di Indonesia mengalami kegagalan dalam pelajaran matematika. Berdasarkan pendapat para guru kelas 6 , beberapa siswa belum menguasai materi sesuai kelasnya. Memprediksi kemampuan siswa pada pelajaran matematika dapat membantu guru dalam menyusun soal ujian yang sesuai dengan kemampuan siswa.

Sebagian besar penelitian menyebutkan bahwa tolak ukur kemampuan siswa adalah nilai ujian akhir sekolah[2]. Data yang digunakan dalam penelitian ini adalah hasil ujian dari 23 siswa kelas 6. Semua siswa mengerjakan 10 paket soal pelajaran matematika bentuk soal pilihan ganda dan setiap paket terdiri dari 40 butir soal. Sehingga total keseluruhan data berasal dari 400 butir soal.

Regresi linear banyak digunakan untuk mengetahui pola hubungan antara dua variable atau lebih[3]. Penelitian berusaha untuk mengetahui hubungan antara kemampuan siswa terhadap tingkat kesulitan soal. Bagian pendahuluan terutama berisi: (1) latar belakang; (2) hasil kajian pustaka; (3) tujuan. Panjang bagian pendahuluan sekitar 2-3 halaman dan diketik dengan 1 spasi (atau mengikuti ketentuan penulisan jurnal ilmiah tempat artikel tersebut hendak diterbitkan).

\section{METODE}

Metodologi yang digunakan dalam penelitian ini seperti pada gambar 1 . Ada 2 data yang digunakan yaitu, tingkat kemampuan siswa dan tingkat kesulitan soal.

[Figure 1 about here.]

\subsection{Soal}

Dalam penelitian ini, data berasal dari hasil tes 23 siswa kelas 6 . Semua siswa mengerjakan 10 paket soal tryout mata pelajaran matematika bentuk soal pilihan ganda dan setiap paket terdiri dari 40 butir soal. Tiap paket soal tryout terdiri dari 8 materi dengan rincian seperti pada tabel 1 Sehingga total keseluruhan soal adalah 400 soal
Hasil tes dianalisis dengan memberi bobot 0 untuk jawaban salah dan bobot 1 untuk jawaban benar. Hasil analisis tersebut seperti pada tabel 2 .

[Table 2 about here.]

\subsection{Deteksi Kemampuan Siswa}

Kemampuan siswa adalah penguasaan siswa terhadap materi. Jawaban benar atau salah merupakan parameter kemampuan siswa.

Tingkat kemampuan siswa terhadap tiap materi diukur dengan

$$
\text { Kemampuan siswa }=\frac{\text { Jumlah jawaban benar }}{\text { Jumlah seluruh soal }}
$$

[Table 3 about here.]

Kelompok tingkat kemampuan siswa dihitung dengan membagi urutan tingkat kemampuan siswa menjadi 3 kelompok menggunakan quartil (Q) seperti gambar 2

[Figure 2 about here.]

Setelah data kemampuan siswa diurutkan dari nilai terkecil sampai terbesar, maka didapat nilai Q1 $=0.66875$ dan nilai $\mathrm{Q} 2=0.900$

\section{[Figure 3 about here.]}

Berdasarkan gambar 3 kemampuan siswa dikelompokkan seperti table 4

[Table 4 about here.]

\subsection{Penentuan Tingkat Kesulitan Soal}

Soal tryout yang dikerjakan siswa dianalisis tingkat kesulitannya oleh guru dengan memberi bobot pada soal tersebut. Bobot 1 untuk soal mudah, bobot 2 untuk soal sedang, dan bobot 3 untuk soal sulit. Analisis tingkat kesulitan soal tampak seperti pada tabel 5

[Table 5 about here.]

Tingkat kesulitan soal dihitung dengan mencari rerata dari seluruh bobot soal dengan rumus

$$
\bar{x}=\frac{1}{n}\left(x_{1}+x_{2}+\cdots+x_{n}\right)
$$

Keterangan :

$$
\begin{aligned}
& \bar{x}=\text { rerata } \\
& x_{i}=\text { nilai sampel } k e i \\
& n=\text { jumlah sampel }
\end{aligned}
$$

[Table 1 about here.] 
Dari rumus tersebut diperoleh score tingkat kesulitan soal seperti pada table 6

[Table 6 about here.]

Dengan indeks tingkat kesulitan soal seperti table 7

[Table 7 about here.]

\section{HASIL}

Prediksi kemampuan siswa menggunakan regresi linear

$$
Y=a+b X
$$

$Y=$ Rerata tingkat kesulitan soal

$X=$ Rerata kemampuan siswa

[Table 8 about here.]

Dari tabel 8, nilai Multiple $\mathrm{R}$ adalah 0,807383817 yang memiliki nilai positif mendekati 1 maka variable bebas dan variable terikat memiliki hubungan yang kuat.

$\mathrm{R}$ square $=0.651868627$ artinya tingkat kesulitan memberikan kontribusi sebesar $65 \%$ terhadap kemampuan siswa, dan ada $35 \%$ pengaruh lain

Standar error memiliki nilai 0.049056497 ini merupakan angka yang sangat kecil artinya model regresi ini semakin tepat dalam menentukan kemampuan siswa.

\section{[Table 9 about here.]}

Pada tabel 9 diperoleh Sig F $=0.01538414$ kurang dari 0,05 artinya variable tingkat kesulitan soal dan variable tingkat kemampuan siswa saling berpengaruh Persamaan regresi linier yang diperoleh adalah

$$
Y=1.118377418-0.151888931 X
$$

Dalam penelitian ini, data analisis hasil belajar siswa dan penentuan tingkat kesulitan guru digunakan untuk memprediksi kemampuan siswa terhadap tingkat kesulitan soal.

\section{KESIMPULAN}

Dengan menggunakan metode regresi linear diketahui ada hubungan yang erat antara kemampuan siswa dengan tingkat kesulitan soal.

\section{REFERENSI}

U. L. Yuhana, R. G. Mangowal, S. Rochimah, E. M. Yuniarno, and M. H. Purnomo, "Predicting Math performance of children with special needs based on serious game," 2017 IEEE 5th Int. Conf. Serious Games Appl. Heal. SeGAH 2017, 2017, doi: 10.1109/SeGAH.2017.7939276.

A. Mohamed, W. Husain, and A. Rashid, "The Third Information Systems International Conference A
Review on Predicting Student, s Performance using Data Mining Techniques," Procedia Procedia Comput. Sci., vol. 72, pp. 414-422, 2015, doi: 10.1016/j.procs.2015.12.157.

C. Zhang and F. Wang, "Research on correlation analysis between test score and classroom attendance based on linear regression model," ICIMA 2010 2010 2nd Int. Conf. Ind. Mechatronics Autom., vol. 1, pp. 545-548, 2010, doi: 10.1109/ICINDMA.2010.5538079. 


\section{DAFTAR TABEL}

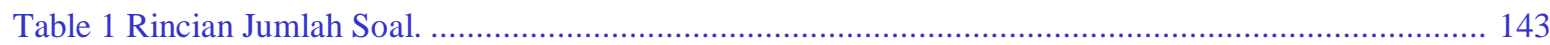

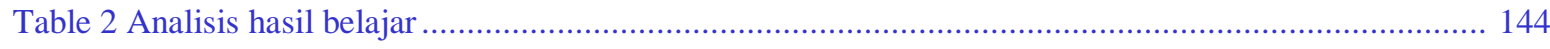

Table 3 Kemampuan siswa berdasarkan kompetensi................................................................... 145

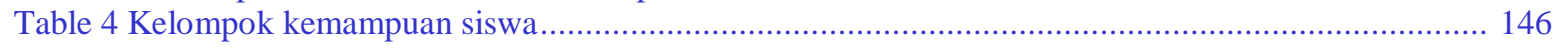

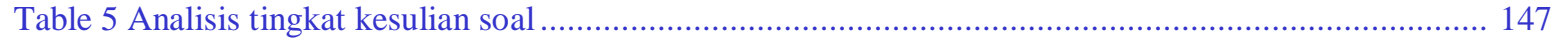

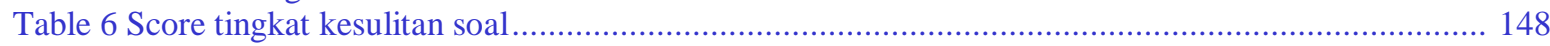

Table 7 Indeks tingkat kesulitan soal ...................................................................................... 149

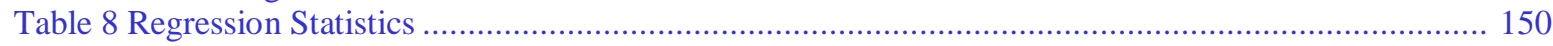

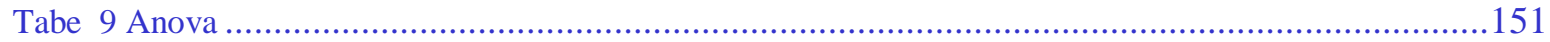


Tabel 1 Rincian jumlah soal

\begin{tabular}{|c|c|c|}
\hline No & Materi & Jumlah Soal \\
\hline 1 & Operasi Hitung (OP) & 30 \\
\hline 2 & KPK dan FPB (KF) & 20 \\
\hline 3 & Pangkat (Pa) & 20 \\
\hline 4 & Pecahan (Pe) & 80 \\
\hline 5 & Satuan Ukur (SU) & 70 \\
\hline 6 & Bangun Datar (BD) & 40 \\
\hline 7 & Bangun Ruang (BR) & 70 \\
\hline 8 & Statistik (St) & 70 \\
\hline \multicolumn{2}{|c|}{ Total Soal } & 400 \\
\hline
\end{tabular}


Tabel 2 Analisis hasil belajar

ANALISIS HASIL BELAJAR

\begin{tabular}{|c|c|c|c|c|c|c|c|c|c|c|c|c|c|c|c|c|c|c|c|c|c|c|c|c|c|c|c|c|c|c|c|c|c|c|c|c|c|c|c|c|c|c|c|}
\hline & & & & & & & & & & & & & & & & & & & & & mor & So & & & & & & & & & & & & & & & & & & & Jum & nlah & \\
\hline & & \begin{tabular}{|l|}
1 \\
\end{tabular} & & 3 & 4 & 5 & 6 & & $\overline{8}$ & & 10 & 11 & 12 & $\mid 13$ & 14 & 15 & 16 & \begin{tabular}{|l|}
17 \\
\end{tabular} & 18 & & & & & & & & & & & 29 & & & & & & & & & & & & & \\
\hline & S1 & 1 & 1 & 1 & 1 & 1 & 1 & 1 & 0 & 1 & & 1 & 1 & & 0 & 0 & 0 & 0 & 0 & 0 & 0 & & 1 & & & 0 & 1 & & & & & & & & & & & 0 & & 1 & 26 & 14 & 65 \\
\hline & S2 & 1 & & 1 & 1 & 0 & 1 & 1 & 0 & & & & 1 & 1 & & 0 & & & 0 & 0 & 0 & 1 & & & & & & & & 0 & & 0 & & & & & & 1 & & 1 & 25 & 15 & 62, \\
\hline & 53 & 1 & 1 & 1 & 1 & 1 & 1 & 1 & 1 & 1 & 1 & 1 & 1 & 1 & 0 & 0 & 0 & 0 & 0 & 1 & 0 & 0 & 0 & 1 & 0 & 0 & 1 & 0 & 0 & 0 & 0 & 0 & & & & & & 0 & 0 & 0 & 22 & 18 & 55 \\
\hline & 54 & 1 & 1 & 1 & 0 & 0 & 0 & 1 & 1 & 0 & 0 & 0 & 1 & 1 & 0 & 1 & 0 & 0 & 1 & 0 & 0 & 0 & 1 & 1 & 0 & 0 & 0 & 0 & 0 & 1 & 0 & 0 & & 1 & & & \begin{tabular}{l|l}
0 & 0 \\
\end{tabular} & 1 & 1 & 0 & 18 & 22 & 45 \\
\hline & $\$ 5$ & 1 & 1 & 1 & 1 & 1 & 1 & 1 & 1 & 1 & 0 & 1 & 1 & 1 & 0 & 0 & 0 & 0 & 0 & 0 & 0 & 1 & 1 & 1 & 1 & 1 & 1 & 0 & 1 & 1 & 0 & 0 & & 0 & & & 1 & 1 & 1 & 1 & 28 & 12 & 70 \\
\hline & S6 & 1 & 1 & 1 & 1 & 0 & 1 & 1 & 1 & 1 & & 1 & 1 & & 0 & & 1 & 0 & 1 & 1 & 0 & 1 & 0 & 1 & 0 & 1 & 1 & 0 & 1 & 1 & 0 & 0 & & & & & & 1 & 0 & 1 & 26 & 14 & 65 \\
\hline 7 & S7 & 1 & 1 & 1 & 1 & 1 & 0 & 1 & 0 & 0 & 0 & 1 & 1 & 1 & 0 & 0 & 0 & 0 & 0 & 1 & 0 & 0 & 0 & 1 & 1 & 1 & 1 & 1 & 1 & 1 & 0 & 0 & & & & & & 0 & 1 & 1 & 24 & 16 & 60 \\
\hline & 58 & 1 & 1 & 1 & 1 & 1 & 0 & 1 & 1 & 0 & 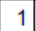 & 1 & 1 & 0 & 0 & 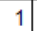 & 1 & 0 & 0 & 0 & 1 & 0 & 0 & 1 & 0 & 0 & 0 & 1 & 1 & 0 & 0 & 0 & & 0 & & & & 0 & 0 & 0 & 20 & 20 & 50 \\
\hline 9 & 59 & 1 & 1 & 1 & 0 & 0 & 1 & 1 & 1 & 1 & 0 & 0 & 1 & 0 & 0 & 0 & 0 & 0 & 1 & 0 & 0 & 0 & 0 & 0 & 0 & 1 & 1 & 1 & 0 & 1 & 0 & 0 & & 0 & & & 0 & & 0 & 1 & 18 & 22 & 45 \\
\hline 10 & $\mathrm{~S} 10$ & 1 & 1 & 0 & 0 & 1 & 0 & 1 & 1 & 1 & 0 & 1 & 1 & 1 & 1 & 0 & 0 & 0 & 0 & 1 & 0 & 0 & 0 & 0 & 0 & 0 & 1 & 0 & 1 & 0 & 0 & 0 & & 1 & & & 1 & 0 & 0 & 0 & 18 & 22 & 45 \\
\hline 11 & S11 & 1 & 1 & 1 & 1 & 1 & 1 & 1 & 1 & 0 & 1 & 1 & 1 & 1 & 0 & 1 & 1 & 0 & 1 & 1 & 0 & 1 & 1 & 1 & 1 & 1 & 1 & 1 & 1 & 1 & 0 & 0 & & 0 & & & & & & 0 & 31 & 9 & 77 \\
\hline 12 & S12 & 1 & 1 & 1 & 1 & 1 & 1 & 1 & 1 & 1 & 1 & 1 & 0 & 1 & 0 & 1 & 1 & 1 & 0 & 1 & 1 & 1 & 1 & 1 & 1 & 1 & 0 & 1 & 1 & 1 & 0 & 0 & 1 & 1 & & & & 0 & 0 & 1 & 32 & \begin{tabular}{|l|}
8 \\
\end{tabular} & 80 \\
\hline 13 & $\mathrm{~S} 13$ & 1 & 1 & 1 & 1 & 1 & 1 & 1 & 0 & 0 & 0 & 1 & 1 & 1 & 1 & 0 & 0 & 0 & 0 & 0 & 0 & 0 & 1 & 1 & 1 & 0 & 1 & 0 & 0 & 1 & 0 & 1 & & 0 & 0 & & 0 & 0 & 1 & 1 & 22 & 18 & 55 \\
\hline 14 & $\mathrm{~S} 14$ & 1 & 1 & 1 & 1 & 0 & 0 & 1 & 0 & 1 & 0 & 0 & 0 & 0 & 1 & 1 & 0 & 0 & 0 & 0 & 0 & 0 & 0 & 1 & 0 & 0 & 0 & 0 & 0 & 1 & 0 & 0 & 1 & 1 & & & 0 & 1 & 1 & 0 & 15 & 25 & 37, \\
\hline 15 & S15 & 1 & 1 & 1 & 1 & 1 & 1 & 1 & 1 & 0 & 1 & 0 & 1 & 1 & 1 & 1 & 1 & 1 & 0 & 1 & 1 & 1 & 0 & 1 & 1 & 1 & 1 & 1 & 1 & 1 & 0 & 0 & & 0 & & & 0 & 0 & 1 & 1 & 31 & 9 & 77,5 \\
\hline 16 & S16 & 1 & 1 & 0 & 1 & 1 & 0 & 1 & 0 & 0 & 0 & 0 & 1 & 1 & 1 & 1 & 0 & 0 & 0 & 1 & 0 & 1 & 0 & 1 & 0 & 0 & 0 & 1 & 1 & 0 & 0 & 0 & 0 & 0 & 0 & 0 & 0 & 1 & 0 & 0 & 15 & 25 & 37,5 \\
\hline 17 & S17 & 1 & 1 & 1 & 1 & 0 & 1 & 1 & 1 & 1 & 0 & 1 & 1 & 1 & 0 & 0 & 0 & 0 & 1 & 0 & 0 & 0 & 0 & 1 & 0 & 1 & 1 & 1 & 1 & 1 & 0 & 0 & 1 & 1 & 1 & 1 & & 0 & 0 & 1 & 23 & 17 & 57,5 \\
\hline 18 & $\mathrm{~S} 18$ & 1 & 1 & 1 & 1 & 0 & 1 & 1 & 1 & 0 & 0 & 1 & 1 & 1 & 0 & 0 & 0 & 1 & 0 & 1 & 0 & 0 & 1 & 1 & 1 & 0 & 1 & 1 & 1 & 1 & 0 & 0 & 1 & 1 & 1 & & & 0 & 0 & 0 & 24 & \begin{tabular}{l|l}
16 \\
\end{tabular} & 60 \\
\hline 19 & $\mathrm{~S} 19$ & 1 & 1 & 1 & 1 & 0 & 1 & 1 & 1 & 1 & 1 & 1 & 1 & 1 & 1 & 1 & 1 & 0 & 1 & 0 & 0 & 0 & 0 & 1 & 0 & 0 & 1 & 0 & 0 & 1 & 0 & 0 & 1 & 1 & 1 & & 1 & 1 & 1 & 1 & 27 & 13 & 67,5 \\
\hline 20 & $\mathrm{~S} 20$ & 1 & 1 & 1 & 1 & 1 & 0 & 1 & 1 & 0 & 1 & 1 & 1 & 1 & 1 & 1 & 0 & 1 & 0 & 1 & 0 & 0 & 0 & 1 & 1 & 0 & 1 & 1 & 0 & 1 & 0 & 0 & 1 & 1 & & & 0 & 1 & 0 & 1 & 27 & 13 & 67, \\
\hline 21 & $\mathrm{~S} 21$ & 1 & 1 & 1 & 1 & 1 & 1 & 1 & 0 & 1 & 1 & 1 & 1 & 1 & 0 & 1 & 1 & 0 & 0 & 0 & 0 & 0 & 1 & 0 & 1 & 0 & 1 & 1 & 1 & 0 & 0 & 0 & 1 & 1 & 1 & 1 & 0 & 0 & 0 & 0 & 23 & 17 & 57,5 \\
\hline 22 & S22 & 1 & 1 & 1 & 1 & 0 & 1 & 1 & 1 & 0 & 0 & 1 & 1 & \begin{tabular}{|l|} 
\\
\end{tabular} & 0 & 0 & 0 & 0 & 0 & 0 & 1 & 0 & 0 & 0 & 0 & 1 & 1 & 0 & 1 & 0 & 0 & 0 & 1 & 0 & 1 & 1 & 1 & 0 & 0 & 1 & 20 & 20 & 50 \\
\hline 23 & $\mathrm{~S} 23$ & 1 & 1 & 1 & 0 & 0 & 0 & 0 & 1 & 0 & 1 & 1 & 1 & \begin{tabular}{|l|} 
\\
\end{tabular} & 0 & 1 & 0 & & & 0 & 0 & 0 & 0 & 1 & 0 & 1 & & 0 & & 1 & 0 & 0 & & 0 & & & 1 & 1 & & 0 & \begin{tabular}{|l|}
19 \\
\end{tabular} & 21 & 47,5 \\
\hline & enar & 23 & & & & & & & & & & & & & & & & & & & & & & & & & & & & & & & & & & & & & & & & & \\
\hline & alah & & & & & & & & & & & & & & & & & & & & & & & & & & & & & & & & & & & & & & & & & & \\
\hline
\end{tabular}


Tabel 3 Kemampuan siswa berdasarkan kompetensi

\begin{tabular}{|c|c|c|c|c|c|c|c|c|c|}
\hline \multirow{2}{*}{ Siswa } & \multicolumn{8}{|c|}{ Kompetensi } & \multirow{2}{*}{$\begin{array}{c}\begin{array}{c}\text { Kemampuan } \\
\text { siswa }\end{array} \\
y\end{array}$} \\
\hline & $x_{1}$ & $x_{2}$ & $x_{3}$ & $x_{4}$ & $x_{5}$ & $x_{6}$ & $x_{7}$ & $x_{8}$ & \\
\hline$S 1$ & 0,80 & 0,70 & 0,75 & 0,63 & 0,63 & 0,58 & 0,64 & 0,76 & 0,68 \\
\hline$S 2$ & 0,93 & 0,90 & 0,95 & 0,85 & 0,77 & 0,93 & 0,84 & 0,79 & 0,87 \\
\hline$S 3$ & 1,00 & 0,95 & 0,90 & 0,79 & 0,66 & 0,70 & 0,73 & 0,79 & 0,81 \\
\hline$S 4$ & 0,70 & 0,50 & 0,55 & 0,49 & 0,26 & 0,48 & 0,51 & 0,64 & 0,52 \\
\hline S5 & 1,00 & 0,95 & 0,95 & 0,86 & 0,87 & 0,85 & 0,90 & 0,93 & 0,91 \\
\hline S6 & 0,93 & 0,70 & 0,85 & 0,71 & 0,56 & 0,63 & 0,73 & 0,84 & 0,74 \\
\hline$S 7$ & 0,90 & 0,90 & 0,80 & 0,76 & 0,71 & 0,73 & 0,70 & 0,83 & 0,79 \\
\hline S8 & 0,63 & 0,85 & 0,80 & 0,61 & 0,59 & 0,50 & 0,76 & 0,79 & 0,69 \\
\hline$S 9$ & 0,90 & 0,60 & 0,95 & 0,74 & 0,69 & 0,65 & 0,79 & 0,84 & 0,77 \\
\hline$S 10$ & 0,90 & 0,85 & 0,80 & 0,76 & 0,74 & 0,68 & 0,77 & 0,80 & 0,79 \\
\hline$S 11$ & 1,00 & 1,00 & 1,00 & 0,93 & 0,94 & 0,93 & 0,93 & 0,94 & 0,96 \\
\hline$S 12$ & 0,97 & 1,00 & 1,00 & 0,86 & 0,91 & 0,90 & 0,87 & 0,87 & 0,92 \\
\hline S13 & 0,83 & 0,90 & 0,95 & 0,71 & 0,73 & 0,75 & 0,64 & 0,79 & 0,79 \\
\hline S14 & 0,70 & 0,50 & 0,75 & 0,55 & 0,47 & 0,48 & 0,56 & 0,64 & 0,58 \\
\hline S15 & 1,00 & 1,00 & 1,00 & 0,83 & 0,89 & 0,93 & 0,86 & 0,86 & 0,92 \\
\hline S16 & 0,67 & 0,55 & 0,60 & 0,58 & 0,26 & 0,33 & 0,47 & 0,56 & 0,50 \\
\hline S17 & 0,83 & 0,85 & 0,95 & 0,80 & 0,63 & 0,58 & 0,71 & 0,74 & 0,76 \\
\hline 518 & 0,90 & 0,90 & 0,95 & 0,70 & 0,70 & 0,73 & 0,79 & 0,76 & 0,80 \\
\hline$S 19$ & 1,00 & 0,80 & 0,90 & 0,83 & 0,77 & 0,68 & 0,74 & 0,87 & 0,82 \\
\hline$S 20$ & 0,97 & 0,85 & 0,70 & 0,86 & 0,69 & 0,73 & 0,79 & 0,86 & 0,80 \\
\hline$S 21$ & 0,83 & 0,85 & 0,90 & 0,64 & 0,54 & 0,60 & 0,69 & 0,73 & 0,72 \\
\hline$S 22$ & 0,97 & 0,80 & 0,90 & 0,68 & 0,60 & 0,73 & 0,76 & 0,80 & 0,78 \\
\hline$S 23$ & 0,73 & 0,50 & 0,50 & 0,70 & 0,44 & 0,63 & 0,60 & 0,69 & 0,60 \\
\hline
\end{tabular}


Tabel 4 Kelompok kemampuan siswa

\begin{tabular}{|l|l|}
\hline Kemampuan Siswa & Score \\
\hline Kemampuan rendah & $<0,66875$ \\
\hline Kemampuan sedang & $0,66875-0,900$ \\
\hline Kemampuan tinggi & $>0,900$ \\
\hline
\end{tabular}


Tabel 5 Analisis tingkat kesulitan soal

\begin{tabular}{|c|c|c|c|c|c|c|c|c|c|c|c|c|c|c|c|c|c|c|c|c|c|}
\hline \multirow{2}{*}{ Guru } & \multicolumn{21}{|c|}{ Nomor Soal } \\
\hline & A1 & A2 & A3 & A4 & A5 & A6 & A7 & A8 & A9 & A10 & \begin{tabular}{|l|l|}
$\ldots$ & A30 \\
\end{tabular} & A31 & A32 & A33 & A34 & A35 & A36 & A37 & A38 & A39 & A40 \\
\hline T1 & 1 & 1 & 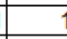 & 1 & 1 & 2 & 2 & 1 & 1 & 2 & 3 & 3 & 1 & 1 & 2 & 1 & 1 & 2 & 3 & 1 & 2 \\
\hline T2 & 1 & 1 & 1 & 1 & 1 & 1 & 1 & 1 & 1 & 2 & 1 & 1 & 1 & 1 & 1 & 1 & 1 & 1 & 1 & 1 & 1 \\
\hline T3 & 1 & 1 & 1 & 1 & 1 & 1 & 2 & 2 & 1 & 2 & 2 & 2 & 3 & 1 & 1 & 1 & 2 & 2 & 3 & 2 & 2 \\
\hline T4 & 1 & 1 & 1 & 1 & 1 & 1 & 1 & 2 & 2 & 1 & 3 & 2 & 1 & 1 & 1 & 1 & 2 & 2 & 1 & 1 & 2 \\
\hline T5 & 1 & 1 & 1 & 1 & 1 & 1 & 1 & 1 & 1 & 1 & 2 & 3 & 2 & 3 & 3 & 3 & 3 & 3 & 2 & 3 & 3 \\
\hline \begin{tabular}{|l|} 
Jumlah \\
\end{tabular} & 5 & 5 & 5 & 5 & 5 & 6 & 7 & 7 & 6 & 8 & 11 & 11 & 8 & 7 & 8 & 7 & 9 & 10 & 10 & 8 & 10 \\
\hline
\end{tabular}


Tabel 6 Score tingkat kesulitan soal

\begin{tabular}{|c|c|}
\hline Kompetensi & Score \\
\hline Operasi Hitung (OP) & 1.84 \\
\hline KPK dan FPB (KF) & 1.78 \\
\hline Pangkat (Pa) & 2.10 \\
\hline Pecahan (Pe) & 2.52 \\
\hline Satuan Ukur (SU) & 2.66 \\
\hline Bangun Datar (BD) & 2.63 \\
\hline Bangun Ruang (BR) & 2.71 \\
\hline Statistik (St) & 2.61 \\
\hline
\end{tabular}


Journal of Electrical and Electronic Engineering-UMSIDA

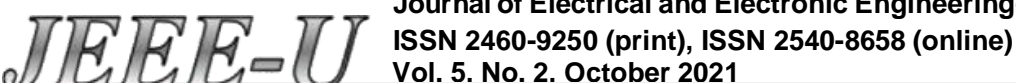

10.21070/jeeeu.v5i2.1459

Tabel 7 Indeks tingkat kesulitan soal

\begin{tabular}{|c|c|}
\hline Indeks & Klasifikasi Soal \\
\hline $2.01-3.00$ & Tinggi \\
\hline $1.01-2.00$ & Sedang \\
\hline $0.00-1.00$ & Mudah \\
\hline
\end{tabular}


Tabel 8. Regression Statistics

\begin{tabular}{|c|c|}
\hline \multicolumn{2}{|c|}{ Regression Statistics } \\
\hline Multiple R & 0.807383817 \\
\hline R Square & 0.651868627 \\
\hline Adjusted R Square & 0.593846732 \\
\hline Standard Error & 0.049056497 \\
\hline Observations & 8 \\
\hline
\end{tabular}


Journal of Electrical and Electronic Engineering-UMSIDA

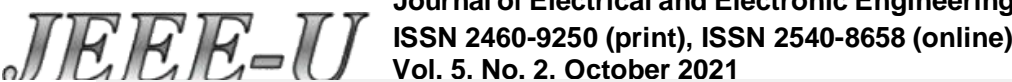

10.21070/jeeeu.v5i2.1459

Tabel 9. Anova

\begin{tabular}{|c|c|c|c|c|c|}
\hline ANOVA & & & & & \\
\hline & $d f$ & $S S$ & $M S$ & $F$ & Sig $F$ \\
\hline Regression & 1 & 0.027037 & 0.027037 & 11.23487 & 0.01538414 \\
\hline Residual & 6 & 0.014439 & 0.002407 & & \\
\hline Total & 7 & 0.041476 & & & \\
\hline
\end{tabular}


DAFTAR GAMBAR

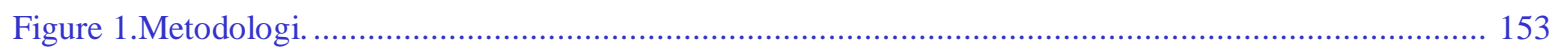

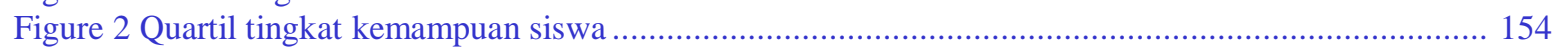

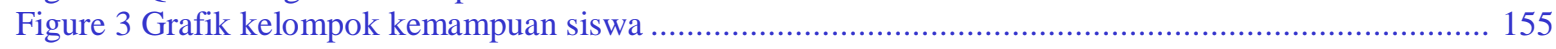


$\pi \sqrt{7} \sqrt{7} \pi \begin{aligned} & \text { Journal of Electrical and Electronic Engineering-UMSIDA } \\ & \text { ISSN 2460-9250 (print), ISSN 2540-8658 (online) }\end{aligned}$

Vol. 5. No. 2. October 2021

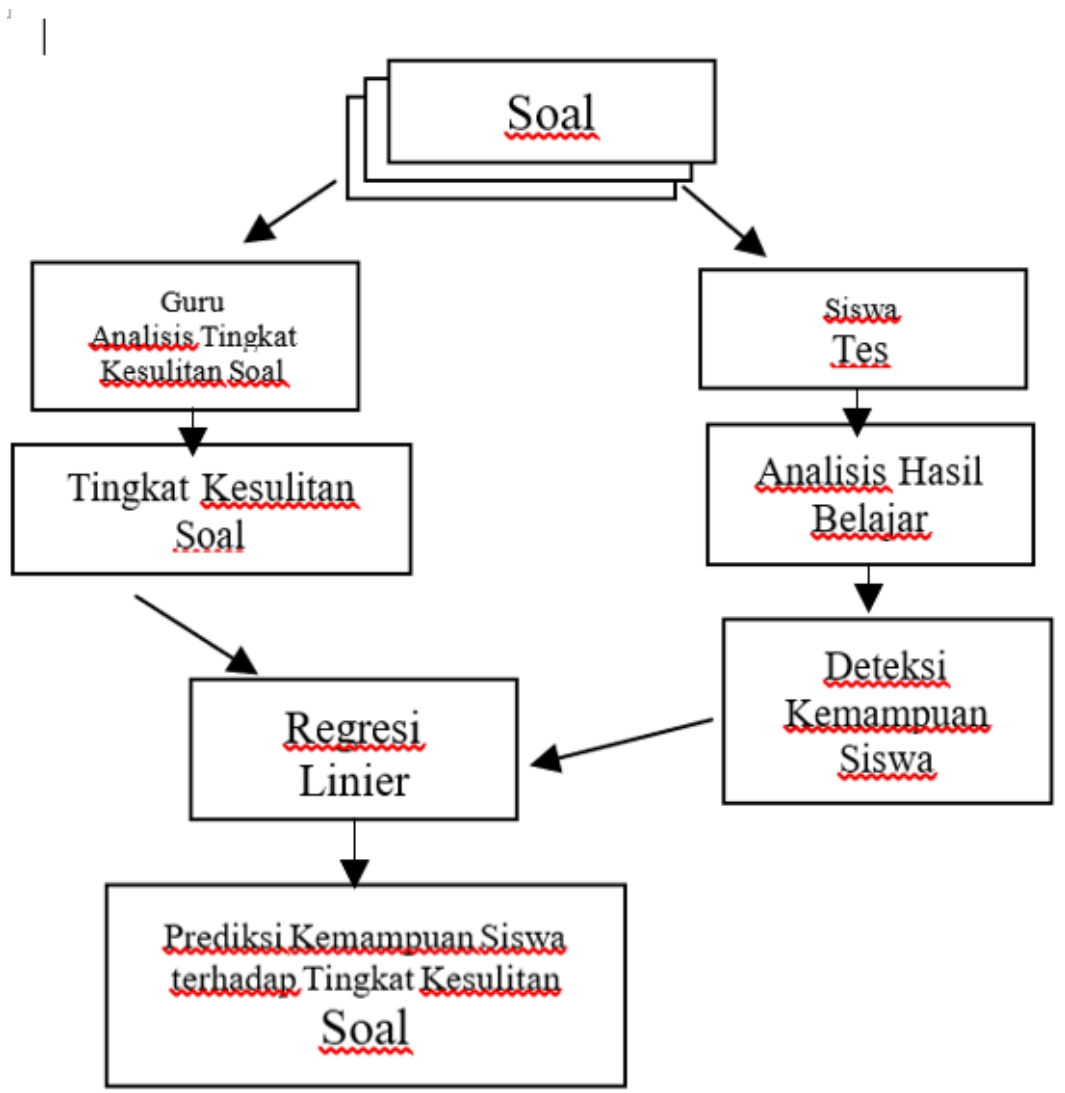

Figure 1. Metodologi 


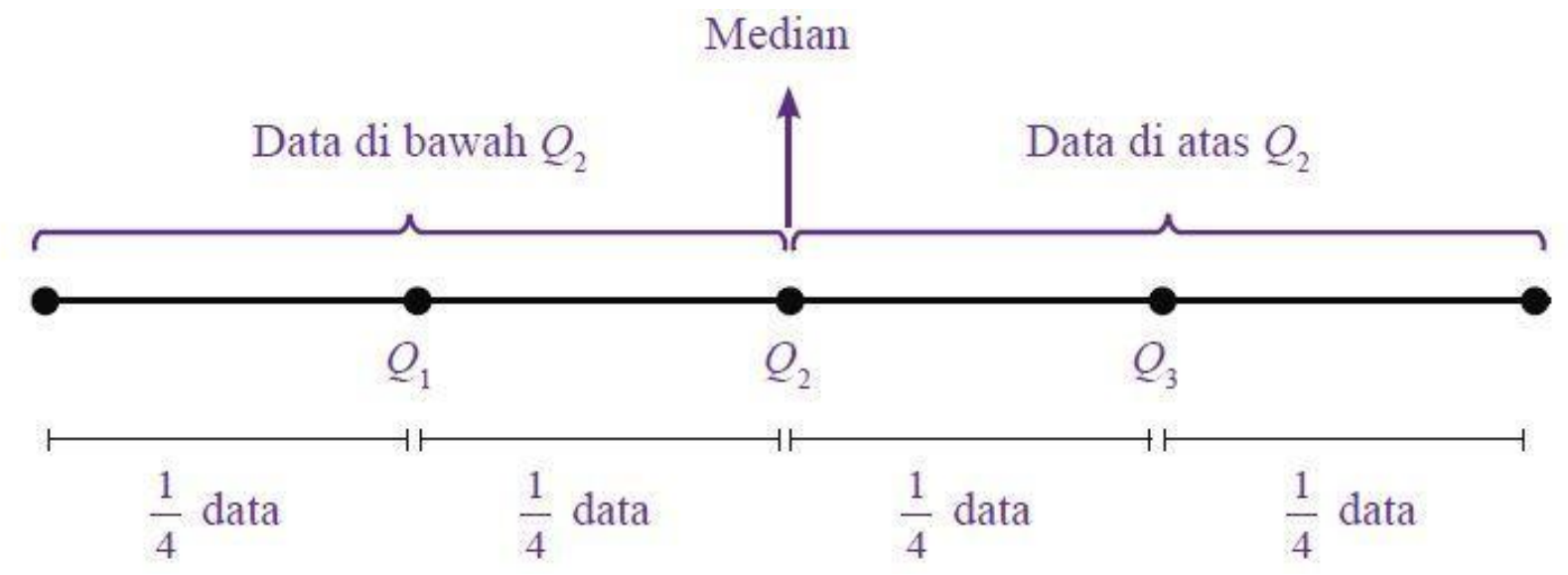

Figure 2. Quartil tingkat kemampuan siswa 


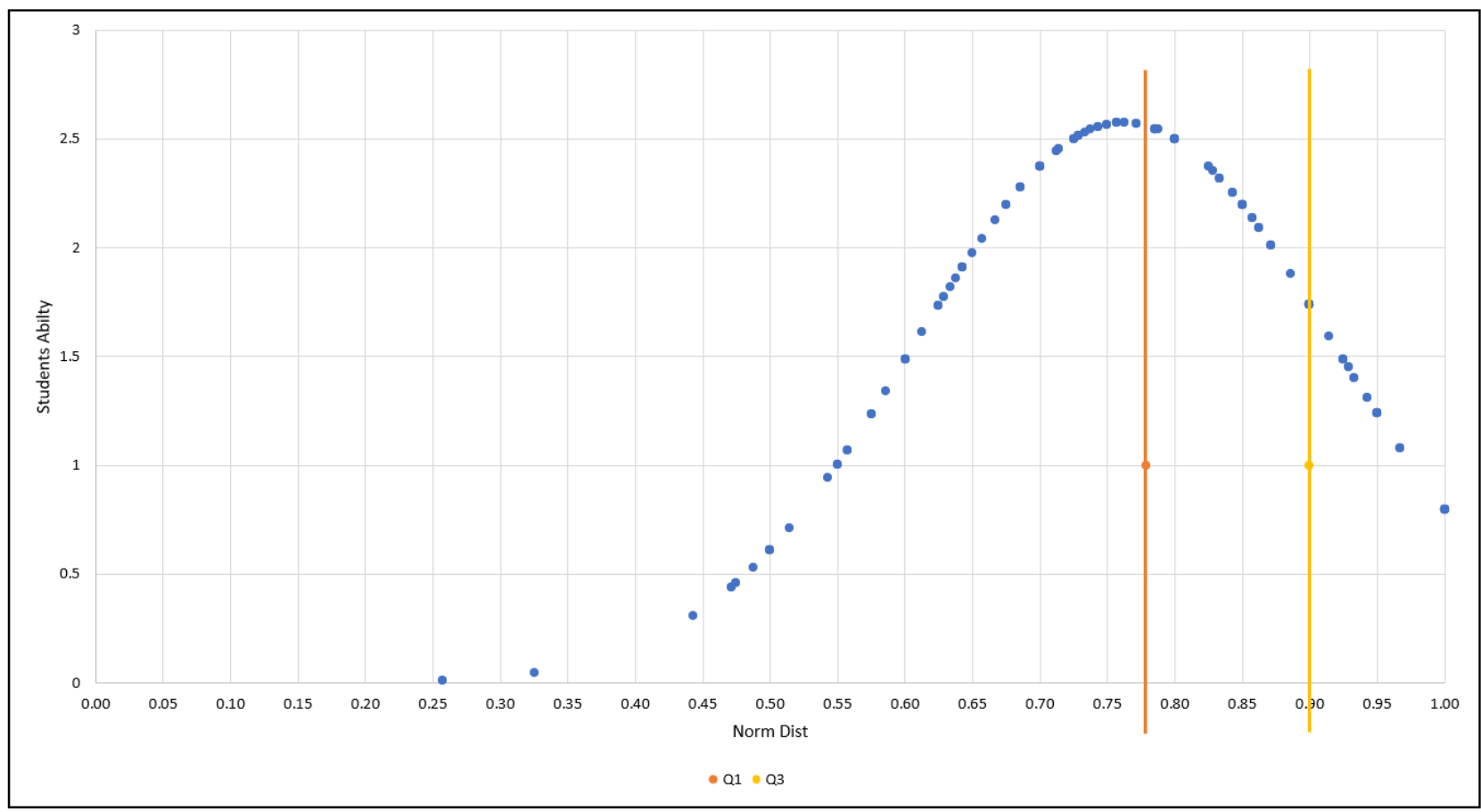

Figure 3. Grafik kelompok kemampuan siswa 